\title{
Malus Domestica Peel Extract Counters Carboplatin Induced Fall in Red Blood Cell Count and Bone Marrow Erythroid Cell Percentage in Mice
}

${ }^{1}$ Abdul Mudabbir Rehan, ${ }^{2}$ Fariha Ahmad Khan, ${ }^{3}$ Qudsia Umaira Khan, ${ }^{4}$ Rabia Naseer Khan, ${ }^{5}$ Zoobia Irum, ${ }^{3}$ Sehrish Zaffar, ${ }^{6}$ Sadia Chiragh

${ }^{I}$ Department of Pharmacology, D. G. Khan Medical College, Dera Ghazi Khan

${ }^{2}$ Department of Pharmacology, Akhtar Saeed Medical and Dental College, Lahore

${ }^{3}$ Department of Physiology, CMH Medical College, Lahore

${ }^{4}$ Department of Pathology, Shahida Islam Medical and Dental College, Lodhran

${ }^{5}$ Department of Pharmacology, CMH Institute of Medical Sciences, Bahawalpur

${ }^{6}$ Department of Pharmacology, Al-Aleem Medical College, Lahore

\begin{abstract}
Introduction: The Chemotherapy-Induced Anemia (CIA) is a complex phenomenon impacted by many treatments and patient related variables. Some variations within CIA are type of chemotherapeutic agent, dose and schedule of administration of agent, type as well as stage of cancer, time of intervention, age, gender, nutritional status and renal function. The variety of patient presentation and symptomatology in CIA is very thought-provoking while setting up widespread measures to oversee ideal administration of treatments. This study will be focused on protective role of apple peel extract (APPE) on carboplatin induced fall in blood RBC count bone marrow erythroid cell percentage in mice.

Aims \& Objective: To evaluate the protective effect of Malus domestica peel extract on carboplatin induced fall in red blood cell count and bone marrow erythroid cell percentage in mice.

Place and duration of study: The study was conducted at Pharmacology Department of Postgraduate Medical institute, Lahore in June 2016. The total duration of study was 1 month.

Material \& Methods: Forty adult male mice were randomly divided into 5 groups $(n=8)$ and maintained on standard diet and water adlibitum. Group A was negative control. Group B was disease control wherein each animal received one dose of $125 \mathrm{mg} / \mathrm{kg}$ carboplatin intraperitoneally. Group C, D \& E experimental groups were administered same dose carboplatin followed by the ethanolic apple peel extract in three different single oral doses of $25,50 \& 75 \mathrm{mg} / \mathrm{kg}$ respectively for 7 days. Blood \& tissue sampling was done on the 8th day. Data was analyzed using Graf Pad prism 7.

Results: Acute Carboplatin anaemia resulted in $4.01 \pm 0.8510^{12} / \mathrm{L}$ RBC Count \& $21.6 \pm 1.06 \%$ bone marrow erythroid cell percentage in Disease Control Group B. Subsequent Apple peel extract administration in a dose of 25,50 and $75 \mathrm{mg} / \mathrm{kg}$ countered carboplatin induced fall in Groups C, D \& E, simultaneously raising RBC counts \& bone marrow erythroid cell percentage to $\left(6.19 \pm 0.70 \times 10^{12} / \mathrm{L} \& 21.3 \pm 1.28 \%\right)\left(6.56 \pm 0.37 \times 10^{12} / \mathrm{L} \& 25.3 \pm 1.04 \%\right)$ and $\left(6.26 \pm 0.74 \times 10^{12} / \mathrm{L} \&\right.$ $23.5 \pm 1.41 \%$.) respectively. The increase in RBC as well as erythroid cell counts was most significant with the dose of $50 \mathrm{mg} / \mathrm{kg}$ and nearing that of healthy control levels (Group A)

Conclusion: Apple Peel Extract effectively prevented carboplatin induced fall in RBC count and erythroid cell percentage and produced most significant results in a dose of $50 \mathrm{mg} / \mathrm{kg}$.
\end{abstract}

Key words: Chemotherapy Induced Anemia (CIA), Carboplatin, Malus domestica, Erythroid cell percentage

\section{INTRODUCTION}

$\mathrm{T}$ he word anemia is taken from the "anaimia", a Greek word which means deficiency of blood. It also denotes the reduced oxygen carrying ability of RBCs in blood and it is associated very commonly with cancers. ${ }^{1}$ Anemia is considered the most common and obstinate haematological issue in cancer patients. ${ }^{2}$ Chemotherapy induced anemia (CIA) occurs due to malignant invasion of healthy tissues which ultimately leads to loss of blood and marrow intrusion with a resultant disruption in erythropoiesis and functional deficiency of iron due to inflammation. ${ }^{3}$ Anemia due to cancer chemotherapy is significant and very important because it may delay or limit treatment as well as cause serious fatigue and diminished life quality of cancer patients. The grading scale for anemia presented by the National Cancer Institute Anemia Scale is as follows: ${ }^{2}$ 
- Grade 0 - haemoglobin ranges from $14-18 \mathrm{~g} / \mathrm{dL}$ for men and $12-16 \mathrm{~g} / \mathrm{dL}$ for women

- Grade 1 - haemoglobin ranges from $10-14 \mathrm{~g} / \mathrm{dL}$ for men and 10-12 g/dL for women

- Grade 2 - haemoglobin ranges from $8-10 \mathrm{~g} / \mathrm{dL}$

- Grade 3 - haemoglobin ranges form $6.5-8 \mathrm{~g} / \mathrm{dL}$

- Grade 4 - haemoglobin $<6.5 \mathrm{~g} / \mathrm{dL}$

- Grade 5 - Death

The patients getting chemotherapy treatment usually have certain other comorbid conditions like insufficient renal function. Approximately, $70 \%$ of cancer patients getting chemotherapy suffer from anemia. ${ }^{4}$ The adjunct care strategies like stem cell support and marrow transplant are crucial to alleviate the cytotoxic chemotherapeutic effects. ${ }^{2}$ The transfusion rates differ in CIA patients, but approximately $50 \%$ of patients with terminal cancer need $\mathrm{RBC}$ transfusion at least once before finishing chemotherapy treatment. ${ }^{5}$ High dose chemotherapy produces higher response rate in cancer patients. ${ }^{2}$ The chemotherapy disturbs all cells which are rapidly dividing, including erythroid progenitor cells in a phenomenon called as eryptosis. ${ }^{6}$ The eryptosis is a process in which erythrocytes destroy and eliminate malfunctioning erythrocytes which prevents hemolysis \& haemoglobin release. ${ }^{7}$ Eryptosis and erythrocyte deficiency lead to anemia and it is worsened by insufficient compensatory erythropoiesis. ${ }^{7}$ Lymphomas, gynecologic \& genitourinary tumors and lung tumors have highest CIA incidence with at least $50 \%-60 \%$ requiring blood or RBC transfusion. ${ }^{2}$

CIA is precipitated by platinum based chemotherapies (Cisplatin and Carboplatin etc.). ${ }^{8}$ The development of platinum induced anemia is dependent upon many factors like an early decline in haemoglobin levels following the treatment, cumulative doses of platinum analogues, old age, therapeutic failure and high amount of outstanding platinum in following the administration. ${ }^{2}$ The mechanisms of CIA due to platinum analogues comprises of direct suppression of erythroid progenitor cells within the bone marrow. ${ }^{9}$

Carboplatin is an anticancer drug which belongs to alkylating class of cancer chemotherapeutic drugs. It is used effectively to treat many cancers. Experimentally, carboplatin has been used to induce myelosuppression in mice. ${ }^{10}$ Carboplatin induces myelosuppression by increasing overall oxidative stress and decrease in the glutathione content inside bone marrow. ${ }^{11}$ It also cross links the DNA and generates oxidative stress products such as malondialdehyde. ${ }^{12}$ Carboplatin suppresses the bone marrow production of red blood cells by interfering with redox reactions inside marrow cavity and shifts the redox equilibrium towards oxidative side, It can be concluded that toxicities of carboplatin are due to increase in the overall oxidative stress inside bone marrow and if this abrupt rise in oxidative stress could somehow be prevented then the serious untoward effects can be avoided.

Various antioxidant compounds like Glutathione, ${ }^{13}$ Squalene ${ }^{14}$ and L-Carnitine ${ }^{11}$ have shown protective effects on carboplatin induced myelotoxicity in animal models.

Apples are the most widely consumed fruit worldwide and contain five major polyphenols. Apple peel contains 3 to 6 times more flavonoids as compared to apple flesh that's why; apple peel extracts have more antioxidant potential than apple flesh extracts. ${ }^{15}$

Apple peel extract by virtue of its antioxidant property has potential to restore the redox equilibrium and improve the peripheral red $\mathrm{RBC}$ count and bone marrow erythroid cell percentage.

We evaluated the protective effect of Malus domestica peel extract on carboplatin induced fall in red blood cell count and bone marrow erythroid cell percentage in mice.

\section{MATERIAL AND METHODS}

Materials used in this research were Apples (red delicious variety), injection Ketamine (Indus Pharma Pvt. Ltd), Injection Carpsol 150mg/15ml (Pfizer Pharma Pvt. Ltd), Electronic balance (Wuhan Panscale Hardware Co. Ltd, Model no. DH-V300A), Hematology analyzer (Sysmex Model no. KX-21, serial no. B 3483), Light microscope (Olympus CHT, Japan), EDTA blood vacutainer (Bio-Vac Stars Pakistan), Whatman filter paper. No.1 (Whatman International Ltd, Maidstone, UK), Giemsa stain (Diachem, China), Hematoxylin \& Eosin stains (Diachem, China), Disposable syringes $3 \& 5 \mathrm{ml}$ (BD syringe Becton Dickinson, Pakistan), Disposable examination gloves (Max Pluss-100, Malaysia).

It was an experimental study conducted at Pharmacology Department of Post Graduate Medical Institute (PGMI), Lahore in June 2016 \& approved by Ethical Committee for Basic Sciences of PGMI. Forty healthy male adult Swiss albino mice, 7-8 weeks of age weighing $25-35 \mathrm{~g}$ were included in the study. Apparently unhealthy-looking mice were excluded Mice were purchased from the University of Veterinary and Animal Sciences (UVAS), Lahore and kept in the Animal House of PGMI under hygienic condition. These were randomly divided via simple lottery method into 5 
groups $(\mathrm{n}=8)$. The temperature was maintained in a range of $19-22^{\circ} \mathrm{C}$, with a natural day and night cycle. Before the onset of study, all mice were kept for a week to acclimatize and they were provided with diet and water ad libitum.

A single intraperitoneal injection of carboplatin (Injection Carpsol $150 \mathrm{mg} / 15 \mathrm{ml}$ by Pfizer Pharma) in a dose of $125 \mathrm{mg} / \mathrm{kg}$ was given to induce myelosuppression in mice. ${ }^{10}$

Red delicious variety of local apples was selected because it contains the richest proportion of antioxidants among all the locally produced varieties. ${ }^{16}$ Apples were washed with plain running water, air dried and peeled carefully so that the peel may not contain flesh. The collected peel was spread and allowed to dry in shade for 2 weeks. The partially dried peels were then put in hot air oven at a temperature of $60^{\circ} \mathrm{C}$ for 3 hours. The completely dried peel was then coarsely ground with pestle and mortar. The powdered peel was soaked in $80 \%$ of ethanol $(1: 10, \mathrm{w} / \mathrm{v})$ at room temperature for 3 days with daily shaking. ${ }^{16}$ The filtration of solution was done by filtering it through Whatman filter paper No. 1 and was separated from the liquid extract. The excess of solvent was evaporated and gummy paste like extract was stored at $4^{\circ} \mathrm{C} .{ }^{16,17}$

The five study groups were given drugs/each mouse as described in the table below.

\begin{tabular}{|c|c|c|}
\hline Mice Groups & $\begin{array}{l}\text { Drug by Intra } \\
\text { peritoneal route } \\
\text { (single dose on } \\
\text { day } 1 \text { only) }\end{array}$ & $\begin{array}{l}\text { Drug by Oral } \\
\text { route (once } \\
\text { daily dose from } \\
\text { day } 1 \text { to } 7 \text { ) }\end{array}$ \\
\hline $\begin{array}{c}\text { A } \\
\text { Normal Control } \\
\end{array}$ & $\begin{array}{c}\text { Sterile water } \\
1.25 \mathrm{ml} / \mathrm{kg}\end{array}$ & $\begin{array}{l}\text { Distilled water } \\
4 \mathrm{ml} / \mathrm{kg}\end{array}$ \\
\hline $\begin{array}{c}\text { B } \\
\text { Disease Control }\end{array}$ & $\begin{array}{l}\text { Carboplatin } \\
125 \mathrm{mg} / \mathrm{kg}\end{array}$ & $\begin{array}{l}\text { Distilled water } \\
4 \mathrm{ml} / \mathrm{kg}\end{array}$ \\
\hline $\begin{array}{c}\mathbf{C} \\
\text { Experimental } 25 \\
\mathrm{mg} / \mathrm{kg} \\
\end{array}$ & $\begin{array}{l}\text { Carboplatin } \\
125 \mathrm{mg} / \mathrm{kg}\end{array}$ & $\begin{array}{c}\text { Apple peel extract } \\
(25 \mathrm{mg} / \mathrm{kg}) \\
25 \mathrm{mg} / 4 \mathrm{ml} / \mathrm{kg} \\
\end{array}$ \\
\hline $\begin{array}{c}\mathbf{D} \\
\begin{array}{c}\text { Experimental } \\
\mathrm{mg} / \mathrm{kg}\end{array} \\
\end{array}$ & $\begin{array}{l}\text { Carboplatin } \\
125 \mathrm{mg} / \mathrm{kg}\end{array}$ & $\begin{array}{c}\text { Apple peel extract } \\
(50 \mathrm{mg} / \mathrm{kg}) \\
50 \mathrm{mg} / 4 \mathrm{ml} / \mathrm{kg}\end{array}$ \\
\hline $\begin{array}{c}\mathbf{E} \\
\text { Experimental } 75 \\
\mathrm{mg} / \mathrm{kg}\end{array}$ & $\begin{array}{l}\text { Carboplatin } \\
125 \mathrm{mg} / \mathrm{kg}\end{array}$ & $\begin{array}{c}\text { Apple peel extract } \\
(75 \mathrm{mg} / \mathrm{kg}) \\
75 \mathrm{mg} / 4 \mathrm{ml} / \mathrm{kg}\end{array}$ \\
\hline
\end{tabular}

Table-1: Summary of drugs administered to all groups

\section{Sampling Technique \& Analyzed Parameters}

1. Blood: Twenty-four hours after the last dose, the mice were anesthetized with ketamine which was administered via single intraperitoneal injection in a dose of $100 \mathrm{mg} / \mathrm{kg}^{17,18}$ into the left lower quadrant of abdomen. The mice were dissected afterwards to expose the heart and $1.5 \mathrm{ml}$ blood was withdrawn directly from the right ventricle with the help of 23-gauge needle and $3 \mathrm{ml}$ disposable syringe. The blood was collected in EDTA vacutainer. ${ }^{17}$

The red blood cell count was analyzed by haematology analyzer

2. Bone Marrow Aspirate: The already dissected mice were euthanized by giving a single sharp cut at neck using surgical scalpel and further dissected to obtain the right femur bone. The contents of right femur were aspirated into $0.2 \mathrm{ml}$ of ice-cold phosphate buffer saline by using 23gauge needle and $10 \mathrm{ml}$ syringe. The aspirate was then spread over slide and smear was prepared. Once the smear was air dried it was dipped into methanol solution to fix the specimen over the slide. Finally, the slide was stained with Geimsa stain, washed with plain running water and cover slip was applied. ${ }^{17,19}$

Differential cell count was done under oil immersion lens of light microscope. 200 cells were counted and relative percentage of red blood cell was entered in the proforma only. ${ }^{17,19}$

\section{Statistical analysis:}

The data was transcribed into GraphPad Prism version 7.0. As data was found to be normally distributed by Shapiro Wilk test, analysis of variance (ANOVA) and post hoc Tukey's test were applied to see which group mean differs. The $p$ value of this hypothesis was $<0.05$ (level of significance).

\section{RESULTS}

\section{Red Blood Cell Count:}

The mean $\mathrm{RBC}$ count \pm standard deviation of all the groups is illustrated in Fig-1. The comparison of means of all groups by ANOVA revealed a significant difference between the group means with a $p$ value of $<0.001$.

The post hoc Tukey's test was applied to analyze the RBC count difference between the groups. The disease control group had markedly lower RBC count as compared to normal control group, whereas all experimental groups had significant higher RBC count as compared to disease control group.

All experimental groups had lower RBC count as compared to normal control and the difference amongst 3 doses of apple peel extract was statistically nonsignificant (Table-2).

\section{Erythroid Cell Percentage:}

The mean erythroid cell percentage \pm standard deviation of all groups is illustrated in Fig-2. The comparison of means of the all groups by ANOVA revealed a significant difference between the group means with a $p$ value of $<0.001$. 


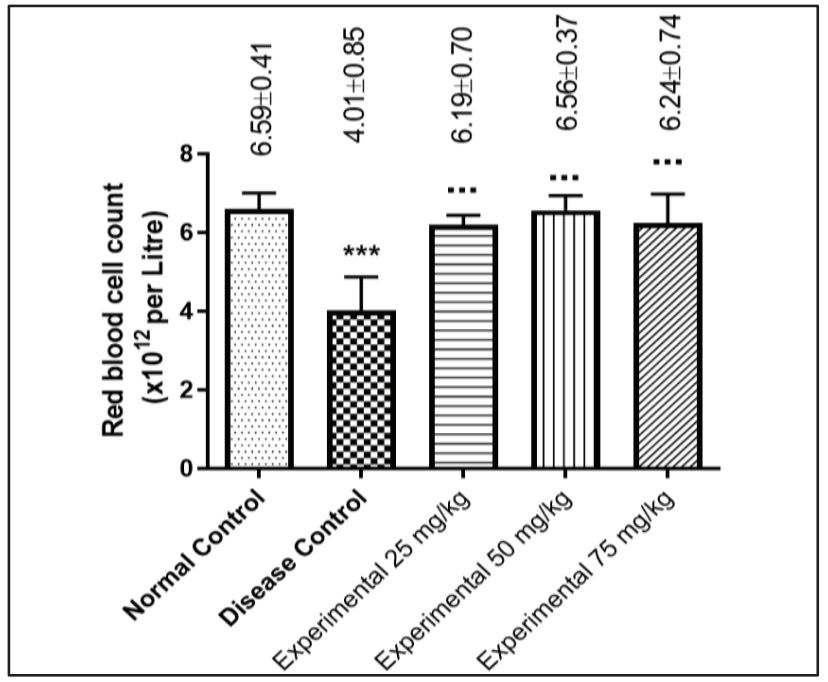

Fig-1: Effect of carboplatin and carboplatin plus 3 different doses of apple peel extract on red blood count (Mean $\pm \mathrm{SD})$ in mice $(\mathrm{n}=8)$

$* * *=p$ value $<0.001$ (vs Normal Control),

$\ldots=p$ value $<0.001$ (vs Disease Control),

..$=p$ value $<0.01$ (vs Disease Control)

\begin{tabular}{|c|c|c|c|}
\hline \multicolumn{2}{|c|}{$\begin{array}{c}\text { Post hoc Tukey's multiple } \\
\text { comparison test }\end{array}$} & \multirow{2}{*}{\begin{tabular}{|c|}
$\begin{array}{c}\text { Mean } \\
\text { difference }\end{array}$ \\
2.57
\end{tabular}} & \multirow{2}{*}{$\begin{array}{c}\text { Significance } \\
* * *\end{array}$} \\
\hline \multirow{4}{*}{$\begin{array}{c}\text { Group A } \\
\text { Normal } \\
\text { control }\end{array}$} & $\begin{array}{l}\text { Disease } \\
\text { control }\end{array}$ & & \\
\hline & $\begin{array}{c}\text { Experimental } \\
(25 \mathrm{mg} / \mathrm{kg})\end{array}$ & 0.40 & $\mathrm{~ns}$ \\
\hline & $\begin{array}{l}\text { Experimental } \\
(50 \mathrm{mg} / \mathrm{kg})\end{array}$ & 0.02 & $\mathrm{~ns}$ \\
\hline & $\begin{array}{c}\text { Experimental } \\
(75 \mathrm{mg} / \mathrm{kg})\end{array}$ & 0.35 & $\mathrm{~ns}$ \\
\hline \multirow{3}{*}{$\begin{array}{c}\text { Group B } \\
\text { Disease } \\
\text { control }\end{array}$} & $\begin{array}{c}\text { Experimental } \\
(25 \mathrm{mg} / \mathrm{kg})\end{array}$ & -2.17 & $* * *$ \\
\hline & $\begin{array}{l}\text { Experimental } \\
(50 \mathrm{mg} / \mathrm{kg})\end{array}$ & -2.55 & $* * *$ \\
\hline & $\begin{array}{c}\text { Experimental } \\
(75 \mathrm{mg} / \mathrm{kg})\end{array}$ & -2.22 & $* * *$ \\
\hline \multirow{2}{*}{$\begin{array}{c}\text { Group C } \\
\text { Experimental } \\
(25 \mathrm{mg} / \mathrm{kg})\end{array}$} & $\begin{array}{c}\text { Experimental } \\
(50 \mathrm{mg} / \mathrm{kg})\end{array}$ & -0.37 & ns \\
\hline & $\begin{array}{c}\text { Experimental } \\
(75 \mathrm{mg} / \mathrm{kg})\end{array}$ & -0.05 & ns \\
\hline $\begin{array}{c}\text { Group D } \\
\text { Experimental } \\
(50 \mathrm{mg} / \mathrm{kg}) \\
\end{array}$ & $\begin{array}{l}\text { Experimental } \\
(75 \mathrm{mg} / \mathrm{kg})\end{array}$ & 0.32 & $\mathrm{~ns}$ \\
\hline
\end{tabular}

Table-2: Comparison of effect of apple peel extract, carboplatin and carboplatin plus 3 different doses of apple peel extract on red blood cell count in mice by post hoc Tukey's test $(n=8)$

ns $=$ not significant, $*=p$ value $<0.05$,

$* *=p$ value $<0.01, * * *=p$ value $<0.001$

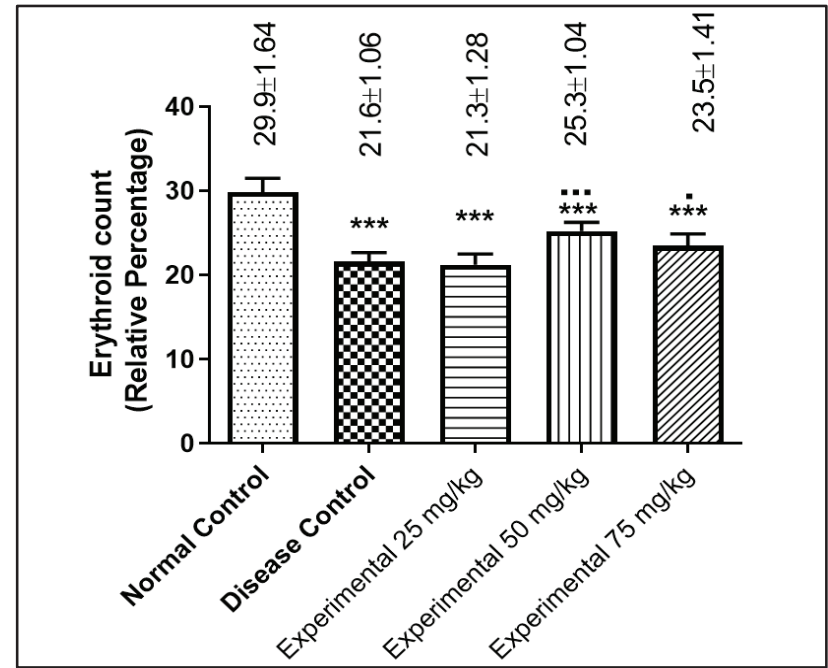

Fig-2: Effect of carboplatin and carboplatin plus 3 different doses of apple peel extract on erythroid cell percentage (Mean \pm SD) in bone marrow aspirate smear of mice $(\mathrm{n}=8)$

$* * *=p$ value $<0.001$ (vs Normal Control),

$* *=p$ value $<0.01$ (vs Normal Control),

$\ldots=p$ value $<0.001$ (vs Disease Control)

\begin{tabular}{|c|c|c|c|}
\hline \multicolumn{2}{|c|}{$\begin{array}{l}\text { Post hoc Tukey's multiple } \\
\text { comparison test }\end{array}$} & \multirow{2}{*}{\begin{tabular}{|c|}
$\begin{array}{c}\text { Mean } \\
\text { difference }\end{array}$ \\
8.25 \\
\end{tabular}} & \multirow{2}{*}{\begin{tabular}{|c|} 
Significance \\
$* * *$
\end{tabular}} \\
\hline \multirow{4}{*}{$\begin{array}{c}\text { Group A } \\
\text { Normal } \\
\text { control }\end{array}$} & Disease control & & \\
\hline & $\begin{array}{l}\text { Experimental } \\
(25 \mathrm{mg} / \mathrm{kg})\end{array}$ & 8.62 & $* * *$ \\
\hline & $\begin{array}{l}\text { Experimental } \\
(50 \mathrm{mg} / \mathrm{kg})\end{array}$ & 4.62 & $* * *$ \\
\hline & $\begin{array}{c}\text { Experimental } \\
(75 \mathrm{mg} / \mathrm{kg})\end{array}$ & 6.37 & $* * *$ \\
\hline \multirow{3}{*}{$\begin{array}{l}\text { Group B } \\
\text { Disease } \\
\text { control }\end{array}$} & $\begin{array}{l}\text { Experimental } \\
(25 \mathrm{mg} / \mathrm{kg})\end{array}$ & 0.37 & ns \\
\hline & $\begin{array}{l}\text { Experimental } \\
(50 \mathrm{mg} / \mathrm{kg})\end{array}$ & -3.62 & $* * *$ \\
\hline & $\begin{array}{c}\text { Experimental } \\
(75 \mathrm{mg} / \mathrm{kg})\end{array}$ & -1.87 & $*$ \\
\hline \multirow{2}{*}{$\begin{array}{c}\text { Group C } \\
\text { Experimental } \\
(25 \mathrm{mg} / \mathrm{kg})\end{array}$} & $\begin{array}{l}\text { Experimental } \\
(50 \mathrm{mg} / \mathrm{kg})\end{array}$ & -4.00 & $* * *$ \\
\hline & $\begin{array}{c}\text { Experimental } \\
(75 \mathrm{mg} / \mathrm{kg})\end{array}$ & -2.25 & $*$ \\
\hline $\begin{array}{c}\text { Group D } \\
\text { Experimental } \\
(50 \mathrm{mg} / \mathrm{kg})\end{array}$ & $\begin{array}{l}\text { Experimental } \\
(75 \mathrm{mg} / \mathrm{kg})\end{array}$ & 1.75 & ns \\
\hline
\end{tabular}

Table-3: Comparison of effect of carboplatin, apple peel extract and carboplatin plus 3 different doses of apple peel extract on erythroid cell percentage in bone marrow aspirate smear of mice by post hoc Tukey's test $(\mathrm{n}=8)$

ns $=$ not significant, $*=p$ value $<0.05$,

$* *=p$ value $<0.01, * * *=p$ value $<0.01$

The post hoc Tukey's test was applied to analyze the erythroid cell percentage difference between the groups. The disease control group had markedly lower erythroid cell percentage as compared to 
normal control, whereas experimental groups 50 \& $75 \mathrm{mg} / \mathrm{kg}$ had significant higher erythroid cell percentage as compared to disease control group.

Experimental $50 \mathrm{mg} / \mathrm{kg}$ group and experimental 75 $\mathrm{mg} / \mathrm{kg}$ group had significant higher erythroid cell percentage as compared to experimental $25 \mathrm{mg} / \mathrm{kg}$ group, whereas difference between experimental 50 $\& 75 \mathrm{mg} / \mathrm{kg}$ was statistically nonsignificant(Table3).

\section{DISCUSSION}

Cancer is the $2^{\text {nd }}$ most common leading cause of death worldwide which causes severe morbidity and mortality in all age groups. Chemotherapy is the prime option for initial medical management of various cancers, but it is the acute or cumulative toxicity of these agents which impairs treatment and ultimately leads to either dose reduction or treatment delay, thus reducing the drug efficacy and quality of life of cancer patients. ${ }^{20}$ The most common dose dependent adverse effects of various chemotherapeutic agents are alopecia, myelosuppression and gastrointestinal irritation, whereas myelosuppression is the only treatment limiting toxicity in almost all of the cancer patients. ${ }^{21}$ That is why adjuvants, neo-adjuvants and adjunct therapies are used along with the principal therapeutic strategy to abate cancers. The GM-CSF has been used in cancer patients to improve peripheral neutrophils, ${ }^{22}$ erythropoietin to promote the production of erythrocytes, ${ }^{23}$ and thrombopoietin to treat thrombocytopenia. ${ }^{24}$ and blood transfusion to improve pancytopenia. However, the indications of the above regimens are limited because of their high costs and serious adverse effects like transfusion related immunomodulation..$^{25,26}$ and risk of tumor growth and shortening of survival with the use of epoetin. ${ }^{2}$ The ultimate solution to chemotherapy induced myelosuppression lies in the natural compounds which can prevent the dose dependent chemotherapy induced myelosuppression by virtue of their antioxidant capacity.

In current study, there was significant decrease in peripheral blood RBC count which was accompanied by a significant decrease in erythroid cell percentage in bone marrow aspirate smear of disease control group. The RBC count and erythroid cell percentage increased significantly in all experimental groups as compared to disease control group and the maximum increase was observed in $50 \mathrm{mg} / \mathrm{kg}$ group. Apple peel extract significantly prevented carboplatin induced oxidative stress in experimental groups and there was rise in $\mathrm{RBC}$ count along with the rise in erythroid cells. In a similar study, significant rise in RBC count was observed in a compound Lycium barbarum polysaccharide. Lycium barbarum polysaccharide in a dose of 50,100 and $200 \mathrm{mg} / \mathrm{kg}$ promoted the peripheral RBC count in carboplatin induced myelosuppressive mice. $^{27}$ In another study conducted by Shim and his colleagues, similar observations were made. Ginsan, a traditional Chinese herbal medicine improved the peripheral blood RBC count in chemotherapy treated mice. ${ }^{28}$ There was 1.5 -fold increase in the blood cell counts in mice which were post-treated with the Ginsan. Ginsan increased the bone marrow cellularity also. The number of bone marrow cells in the mice treated with Ginsan increased from $17.45 \pm 0.07$ in the chemotherapy treated group to $22.55 \pm 0.19 \mathrm{x}$ $10^{6}$ cells $(p$ value $<0.05$ ). The increase in the bone marrow cellularity is a remarkable effect which depicts the protective effect of Ginsan just like the apple peel extract. No comparable studies on apple peel extract were found.

In current study, three different doses of apple peel extract were used to find out the right therapeutic dose. The study results demonstrated that all three doses of apple peel extract caused an overall numerical increase in the peripheral RBC count and bone marrow cellularity of all experimental groups, but statistical analysis revealed that the apple peel extract in a dose of $50 \mathrm{mg} / \mathrm{kg}$ is more significant as compared to the rest of 2 doses. The significantly better results of $50 \mathrm{mg} / \mathrm{kg}$ dose as compared to 25 $\mathrm{mg} / \mathrm{kg}$ dose demonstrates dose dependent preventive effect, while inferior effect of $75 \mathrm{mg} / \mathrm{kg}$ dose may be explained by the fact that antioxidants in a high dose act as pro-oxidants. Adulteration and contamination of medicinal plants with transition metal ions such as copper and iron can aggravate the pro-oxidant effects of medicinal plants by catalyzing oxidation reactions. Besides, polyphenols are metabolized by Phase I and Phase II enzymes, and their metabolism can produce intermediate and final metabolites and reactive oxygen species (ROS) with prooxidants properties. While cells exposed to medicinal extracts at short exposure times and low concentrations usually show increased cell viability, the powerful antioxidant extracts in high concentrations have been found to be cytotoxic by inducing severe oxidative stress ${ }^{29}$

\section{CONCLUSION}

Apple peel extract is effective in preventing the fall in red blood cell count \& erythroid cell percentage induced by the carboplatin driven oxidative stress. Apple peel extract produced most significant results in a dose of $50 \mathrm{mg} / \mathrm{kg}$. 


\section{Acknowledgement:}

Authors are thankful to staff of Animal House and Chemical Pathology Laboratory of Postgraduate Medical Institute, Lahore for their cooperation.

\section{REFERENCES}

1. Radziwon P, Krzakowski M, Kalinka-Warzocha E, Zaucha R, Wysocki P, Kowalski D, et al. Anaemia in cancer patients - Expert Group recommendations. Oncology in Clinical Practice. 2017; 13(5):202-10.

2. Bryer E, Henry D. Chemotherapy-induced anemia: etiology, pathophysiology, and implications for contemporary practice. International Journal of Clinical Transfusion Medicine. 2018; 6:21.

3. Gilreath JA, Stenehjem DD, Rodgers GM. Diagnosis and treatment of cancer related anemia. American journal of hematology. 2014; 89(2):203-12.

4. Barrett-Lee PJ, Ludwig H, Birgegård G, Bokemeyer C, Gascón P, Kosmidis PA, et al. Independent risk factors for anemia in cancer patients receiving chemotherapy: results from the European Cancer Anaemia Survey. Oncology. 2006; 70(1):34-48.

5. Adamson JW. The anemia of inflammation/ malignancy: mechanisms and management. ASH Education Program Book. 2008; 2008(1):159-65.

6. Taylor SJ, Duyvestyn JM, Dagger SA, Dishington EJ, Rinaldi CA, Dovey OM, et al. Preventing chemotherapy-induced myelosuppression by repurposing the FLT3 inhibitor quizartinib. Science translational medicine. 2017; 9(402).

7. Lang E, Lang F. Triggers, inhibitors, mechanisms, and significance of eryptosis: the suicidal erythrocyte death. BioMed Research International. 2015: 1-16.

8. Bamias A, Aravantinos G, Kalofonos C, Timotheadou N, Siafaka V, Vlahou I, et al. Prevention of anemia in patients with solid tumors receiving platinum-based chemotherapy by recombinant human erythropoietin (rHuEpo): a prospective, open label, randomized trial by the Hellenic Cooperative Oncology Group. Oncology. 2003; 64(2):102-10.

9. Spivak JL, Gascón P, Ludwig H. Anemia management in oncology and hematology. Oncologist. 2009; 14(Suppl 1):43-56.

10. Tahir N, Zaheer Z, Kausar S, Chiragh S. Prevention of fall in platelet count by Carica papaya leaf juice in carboplatin induced thrombocytopaenia in mice. Biomedica. 2014; 30(1).

11. Abd-Allah AR, Al-Majed AA, Al-Yahya AA, Fouda SI, Al-Shabana OA. L-Carnitine halts apoptosis and myelosuppression induced by carboplatin in rat bone marrow cell cultures (BMC). Archives of toxicology. 2005; 79(7):406-13.

12. Weijl N, Elsendoorn T, Lentjes E, Hopman G, Wipkink-Bakker A, Zwinderman A, et al. Supplementation with antioxidant micronutrients and chemotherapy-induced toxicity in cancer patients treated with cisplatin-based chemotherapy: a randomised, double-blind, placebo-controlled study. European Journal of Cancer. 2004; 40(11):1713-23.

13. Pratibha R, Sameer R, Rataboli PV, Bhiwgade DA, Dhume CY. Enzymatic studies of cisplatin induced oxidative stress in hepatic tissue of rats. European journal of pharmacology. 2006; 532(3):290-3.

14. Das B, Yeger H, Baruchel H, Freedman M, Koren G, Baruchel S. In vitro cytoprotective activity of squalene on a bone marrow versus neuroblastoma model of cisplatin-induced toxicity: implications in cancer chemotherapy. European Journal of Cancer. 2003; 39(17):2556-65.

15. Karaman Ş, Tütem E, Başkan KS, Apak R. Comparison of antioxidant capacity and phenolic composition of peel and flesh of some apple varieties. Journal of the Science of Food and Agriculture. 2013; 93(4):867-75.

16. Manzoor M, Anwar F, Saari N, Ashraf M. Variations of antioxidant characteristics and mineral contents in pulp and peel of different apple (Malus domestica Borkh.) cultivars from Pakistan. Molecules. 2012; 17(1):390-407.

17. Rehan AM,Khan RN, Zaffar S, Malik M, Chiragh S, Hafeez A. Protective effect of Malus domestica (apple) peel extract on carboplatin induced fall in blood platelet count and bone marrow megakaryocyte percentage in mice. Esculapio. 2020; 16(2):5.

18. Xu Q, Ming Z, Dart AM, Du XJ. Optimizing dosage of ketamine and xylazine in murine echocardiography. Clinical and Experimental Pharmacology and Physiology. 2007;34(56):499-507

19. Gibson FM, Michael Andrews C, Diamanti P, Rizzo S, Macharia G, GordonSmith EC, et al. A new model of busulphan induced chronic bone marrow aplasia in the female $\mathrm{BALB} / \mathrm{c}$ mouse. International journal of experimental pathology. 2003; 84(1):31-48.

20. Huitema A, Spaander M, Mathôt R, Tibben M, Holtkamp M, Beijnen J, et al. Relationship between exposure and toxicity in high-dose chemotherapy with cyclophosphamide, thiotepa and carboplatin. Annals of oncology. 2002; 13(3):374-84.

21. Wang Y, Probin V, Zhou D. Cancer therapy-induced residual bone marrow injury: mechanisms of induction and implication for therapy. Current cancer therapy reviews. 2006; 2(3):271-9.

22. Bennett CL, Djulbegovic B, Norris LB, Armitage JO. Colony-stimulating factors for febrile neutropenia during cancer therapy. New England Journal of Medicine. 2013; 368(12):1131-9.

23. Debeljak N, Solár P, Sytkowski AJ. Erythropoietin and cancer: the unintended consequences of anemia correction. Frontiers in immunology. 2014; 5:563.

24. Kuter DJ. Managing thrombocytopenia associated with cancer chemotherapy.Oncology.2015;29(4):282

25. Blajchman M. Transfusion immunomodulation or TRIM: what does it mean clinically? Hematology. 2005; 10(sup1):208-14.

26. Smith TJ, Bohlke K, Lyman GH, Carson KR, Crawford J, Cross SJ, et al. Recommendations for 
the use of WBC growth factors: American Society of Clinical Oncology clinical practice guideline update. Journal of Clinical Oncology. 2015;33(28):3199-212

27. Gong H, Shen P, Jin L, Xing C, Tang F. Therapeutic effects of Lycium barbarum polysaccharide (LBP) on irradiation or chemotherapy-induced myelosuppressive mice. Cancer biotherapy \& radiopharmaceuticals. 2005; 20(2):155-62.

28. Shim J, Han Y, Ahn J, Yun Y, Song J. Chemoprotective and adjuvant effects of immunomodulator ginsan in cyclophosphamidetreated normal and tumor bearing mice. International journal of immunopathology and pharmacology. 2007; 20(3):487-97.

29. Nasri H, Rafieian-Kopaei M. Medicinal plants and antioxidants: why they are not always beneficial? Iranian journal of public health. 2014; 43(2):255.

\section{The Authors:}

Dr. Abdul Mudabbir Rehan

Assistant Professor,

Department of Pharmacology,

D. G. Khan Medical College, Dera Ghazi Khan.

Dr. Fariha Ahmad Khan

Assistant Professor,

Department of Pharmacology,

Akhtar Saeed Medical and Dental College, Lahore.
Dr. Qudsia Umaira Khan

Assistant Professor,

Department of Physiology,

CMH Medical College, Lahore.

Dr. Rabia Naseer Khan

Assistant Professor,

Department of Pathology,

Shahida Islam Medical and Dental College, Lodhran

Dr. Zoobia Irum

Assistant Professor,

Department of Pharmacology,

CMH Institute of Medical Sciences, Bahawalpur.

Dr. Sehrish Zaffar

Assistant Professor,

Department of Pharmacology,

CMH Medical College, Lahore.

Prof. Sadia Chiragh

Department of Pharmacology,

Al-Aleem Medical College, Lahore.

\section{Corresponding Author:}

Dr. Abdul Mudabbir Rehan

Assistant Professor,

Department of Pharmacology,

D. G. Khan Medical College, Dera Ghazi Khan.

E-mail: abdulmudabbir@yahoo.com 